\title{
Commentary
}

\section{Commission on Accreditation of Athletic Training Education (CAATE): Transition from Bachelor to the Entry-Level Master's-A Changing Landscape for Athletic Training Education}

\author{
Benito J.Velasquez, DA, LAT, ATC* \\ Department of Sport \& Exercise Science, School of Allied Health Sciences, Lincoln Memorial University, 6965 Cumberland Gap Parkway, Harrogate,TN 37752, USA \\ "Corresponding author \\ Benito J.Velasquez, DA, LAT, ATC \\ Chair \& Associate Professor, Department of Sport \& Exercise Science, School of Allied Health Sciences, Lincoln Memorial University, \\ 6965 Cumberland Gap Parkway, Harrogate,TN 37752, USA; E-mail: benito.velasquez@LMUnet.edu
}

\section{Article information}

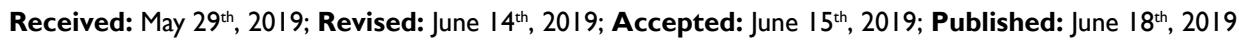

\section{Cite this article}

Velasquez BJ. Commission on accreditation of athletic training education (CAATE):Transition from bachelor to the entry-level master's-a changing landscape for athletic training education. Sport Exerc Med Open J. 2019; 5(I): 2I-22. doi: 10.17I40/SEMOJ-5-17I

\section{ABSTRACT}

Athletic training education is undergoing many changes since the decision was made to move from the bachelor's degree to the master's degree for entry into the profession. Small colleges and universities are reviewing if they choose to transition from an existing undergraduate degree in athletic training to an entry-level Master's degree; or starting a Master's program from the ground up. This article will discuss some of the concerns such as student enrollment, CAATE Standards 11 and 41 , and institutional resources including hiring of new faculty that need to be reviewed before taking the next step to transitioning or starting a new entry-level Master's athletic training program. In addition, there will be discussion of the current status of master's programs and their future.

Keywords

Health-care professionals; Graduate health professions education; Curriculum; Small colleges/universities.
}

T he landscape of the athletic training education program is changing. This is not new, this has been going on for almost five years. However, looking at small colleges and universities that offer athletic training education, this could be disastrous. I wish to point out the future of Athletic Training education is a changing landscape in more than one way. Let me explain; for years, the bachelor's degree in athletic training was the entry-level degree for sitting for the national board exam, (the Board of Certification exam or BOC). In 2015, there were major changes made to the process of preparing students to enter the profession of Athletic Training. The Strategic Alliance composed of the BOC; the Commission on Accreditation of Athletic Training Education, (CAATE); the National Athletic Trainers Association, (NATA); and the NATA Foundation, announced that the professional degree for Athletic Training be the master's degree.
By the fall of 2022, any student entering an education program for the professional preparation of becoming an athletic trainer, must be enrolled in a master's level program. ${ }^{2}$ Since that announcement, many athletic training programs have made the decision to transition their baccalaureate programs to the master's degree, or have closed their athletic training education programs. This is just one change to the educational landscape. According to the CAATE website, ${ }^{1}$ there are over two hundred and thirty-five bachelor degree programs in Athletic Training. Over sixty-seven programs have completed the steps to voluntary withdraw their CAATE accreditation and either close or transition their programs to the entry-level Master's degree in athletic training. Of those sixty-seven programs, thirty-nine are listed as Probation/ Voluntary Withdrawal of Accreditation., ${ }^{2,3}$ The majority of these thirty-nine are on probation for failure to maintain CAATE Standard 11 , which is the three-year aggregate for $70 \%$ first-time pass 
rate on the BOC. An additional seventeen programs are listed on the CAATE website, as probation for not maintaining compliance with Standard $11,{ }^{2,3}$ but have not indicated if they are going to transition or close their program.

As of this writing, thirteen programs have pending action for a degree change from bachelor-level to entry-level Master's. ${ }^{2}$

In terms of the entry-level Master's degree, there are currently, one hundred, thirty-three (133) CAATE accredited programs. There are nineteen new programs seeking initial accreditation, which translates to hiring two new faculty, purchasing or leasing modalities and rehabilitation equipment, in addition finding a space for teaching and labs. This could be a substantial investment by the institution.

A common problem with both bachelor and master's programs is maintaining CAATE Standard 11, which is not achieving a 3-year aggregate of $70 \%$ first-time pass rate on the national Board of Certification exam. Of the Master's programs, nine programs are currently on probation for Standard 11. A surprising review of Master's programs is the number seeking Voluntary Withdrawal of accreditation. Five masters programs have been accepted for Voluntary Withdrawal. This is another change to the educational landscape. You see, years back some programs made the decision to transition from the bachelor's degree to the master's degree. Now, however, we are seeing master's programs in athletic training closing their doors.

In my opinion, there are several reasons for master's programs in athletic training closing down and specifically, this is among small colleges and universities. This trend may continue. One reason is access to resources and institutional support. Administrators at small colleges and universities, especially schools in the private sector (not state-supported); look at tuition dollars to fund the professional programs such as nursing, physical therapy and medicine. These programs are dependent on the number of students admitted as well as their tuition dollars. Which brings up another point, the number of faculty to be compliant with the CAATE standards. As of now, two faculty members are needed one to serve as program director, and the other as clinical coordinator. $^{2}$ It is not unusual to have a faculty budget line in excess of $\$ 100,000$. This is a conservative estimate since both faculty likely have a terminal degree. In addition, the institution would pay benefits and health insurance and this could cost an institution an additional $\$ 2500$ or more per faculty. Another concern on the horizon is after July 1, 2023, institutions will need to be compliant with Standard 41, which states an accredited program must have a minimum of three core faculty members to meet the needs of the athletic training program.

Supporting a program requires tuition dollars. A major concern is the number of students being recruited to the college or university. Cohorts of less than eight students cannot substantiate the costs of running a program, especially if the program is to be self-sustaining. The funding of faculty positions, costs for the program and supporting lab equipment can add up. Unless the cost is put on the student fees, the institution needs to come up with this money. If a college administrator would look at the pro forma budget in preparing to start a program, the institution may be spending a huge amount to start up or maintain a program with little return on the tuition dollars.

Standard 11 compliance can become another reason a program failure. Programs that fail to maintain a 3-year aggregate of $70 \%$ first-time pass rates will result in probation. Probation may result in a cascade of events: decreased enrollment, decreased enrollment with supporting three faculty, may result in the institution closing the program because it's too expensive to support.

In summary, administrators at small colleges and universities need to conduct a critical analysis of their institution. This will require an honest assessment of current resources and financial commitment before trying to implement a transition or start a new athletic training master's degree program.

\section{ACKNOWLEDGEMENTS}

I am disclosing that I serve as a Commission on Accreditation of Athletic Training Education (CAATE) accreditation site-visitor and self-study reader in which I am compensated when I perform these duties for the CAATE, but I am making my own comments and statements and that my comments and statements are not endorsed by or are the opinion of the CAATE.

\section{REFERENCES}

1. Strategic Alliance Statement of May 2015. https://caate.net/ wp-content/uploads/2015/05/Strategic-Alliance-CCATE-emailpdf.pdf. Accessed May 29, 2019.

2. Commission on Accreditation of Athletic Training Education, Search of Professional Programs. https://caate.net/search-foraccredited-program/. Accessed May 29, 2019.

3. Commission on Accreditation of Athletic Training Education, Standards for Accreditation of Professional Athletic Training Programs. https://caate.net/pp-standards/. Accessed May 29, 2019. 